きなやりがいにつながっている.

\title{
文献
}

1）白石吉彦．隠岐島前病院における「地域ブロック制」について，全国自治 体病院協議会雑誌. 2007, vol. 46, no. 3, p. 11-16.

2) 鿵岐島前病院ホームページ. http://okidozenhospital.com/

3）白石吉彦. 隱岐島前病院の取り組み. 日本遠隔医療学会雑誌. 2008, vol. 4, no. 2, p. 220-221.

4）白石吉彦. 地域医療システム論, 市町村の事例 Part 1 (島根県隠岐郡西) 島町ほか)。地域医療テキスト, 2009, p. 112-120。

\section{Primary care in remote islands}

\section{離島医療}

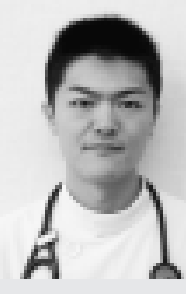

2001 年自治医科大学を卒業し, 札幌医 科大学地域医療総合医学講座に所属す る. その後, 松前町立松前病院, 道立焼 尻診療所，市立根室病院等を経て，2008 年から利尻島国保中央病院に赴任. 義務 年限終了後も，医療ニーズに合わせた離 島医療の充実を目標に島に残留.

研修医教育にも興味があり, 研修医を 多く受け入れて, 離島医療のおもしろさ, 自分の仕事が地域から喜ばれていること を肌で感じてもらっている.

\section{中川 紘明}

漫画やテレビの影響もあって,「離島医療」と聞くと, 医師一人の無床 診療所を想像しがちである。しかし, 離島といっても, 人口は数百人〜 数万人まで様々であり, 本土との位置関係, 交通アクセスも様々である ことから, 当然求められる医療も異なってくる.つまり,「離島医療」を 定義することは難しいと思われる，だだ，島の大小にかかわらず，共通

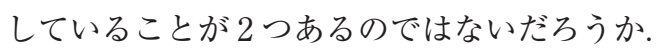

1 つ目は救急搬送. 悪天候の時こそ島民は病気への不安が強くなる が，医師はなおさら頭を悩ませる。翌日まで待てるか，今すぐ搬送した ほうがよいか，時には天候を読んで搬送の決断をしなければならない. つまり，天候・搬送手段を考慮した，“本土”にはない，より高度な能力 が必要となり，これが「離島」で働く医師の確保を難しくしている．プ レッシャーは多いが，元気な姿で帰ってきた患者さんをみると大変うれ しく思い, 離島医療を長く続ける糧となっていることは間違いない.

2 つ目は親近感. 離島という限られた空間では, 相手の顔をよく知り つつ，医療ニーズに合わせた理想的な医療を“本土”以上に提供できる. そして, 病院内だけでなく, 地域全体に目を向けることで, 医療を通じ て地域を盛り上げていくことが出来る.

離島には，地域医療のエッセンスがつまっており，プライマリ・ケア 医を目指すには最適な環境・学びの場ではないかと思っている，離島で 仕事できることを誇りに思いたい.

中川紘明（なかがわ ひろあき）

利尻島国保中央病院

（广 097-0401 利尻郡利尻町沓形字緑町 11 番地 e-mail : rishirih@ruby.ocn.ne.jp） 